\title{
Compositional Studies on Mangalitsa Meat Products for Public Consumption
}

\author{
Ionuț CORDIŞ ${ }^{1}$, Marian MIHAIU ${ }^{1}$, Alexandra TĂBĂRAN ${ }^{1 *}$, Romolica MIHAIU ${ }^{2 *}$, Sorin Daniel DAN ${ }^{1}$, Oana \\ REGET $^{1}$, Darius CORDEA ${ }^{1}$, Carmen MUREŞAN ${ }^{1}$ \\ ${ }^{1}$ Faculty of Veterinary Medicine, University of Agricultural Sciences and Veterinary Medicine, Mănăştur \\ Street, no.3/5, Cluj-Napoca, Romania \\ ${ }^{2}$ Department of Food Management, Babes-Bolyai University Cluj-Napoca, Romania. \\ Corresponding author: lapusan_alexandra@yahoo.com
}

Bulletin UASVM Veterinary Medicine 72(1) / 2015,

Print ISSN 1843-5270; Electronic ISSN 1843-5378

DOI:10.15835/buasvmcn-vm: 10568

\begin{abstract}
Mangalitsa pigs are beginning to receive once again the public and media attention given the particular nutritive aspects compared to other types of breeds. The aim of our study was to assess the biochemical composition of Mangalitsa meat, related to various anatomical regions of the carcass. The main parameters that were taken into study were represented by: protein, water, collagen, fat, fatty acids and cholesterol levels. The material was represented by 10 Mangalitsa pigs, Blod variety, raised in a traditional farm system and slaughtered at 1 year. Our results show a large variability in the protein and water content compared to the anatomical region from where the meat was obtained. The cholesterol values showed no difference among the Mangalitsa meat and the ones obtained from other meat producing species. The lard contains 3 times less the cholesterol in butter. We have concluded that the Mangalitsa meat can be considered a functional product which deserves to be reintroduced in the Romanian food market. We recommend the Mangalitsa meat consumption in favour of other types of pork meat provided by other selected breeds.
\end{abstract}

Keywords: Mangalitsa, pork, protein, fatty acids.

\section{INTRODUCTION}

Pork meat represents an excellent source of nutritive compounds which are essential in human diet. The composition and quality of pork meat is greatly influenced by the breeding conditions (Alonso et al., 2010). The meat quality of animals that bred in natural environments is higher due to the variety of feed and also slower fattening. The fat percent in meat may vary due to factors such as breed, age, sex, health conditions and feeding regime. The taste of pork meat is also dependent of the fat layer, feed and of course breed (Alonso et al., 2010). Most of the consumers are influenced when buying pork meat by these particular aspects.

In general, the breeds that were not so intensively selected from a genetic point of view are the ones which are not so productive but with a greater quality and taste. The meat and products obtained from Mangalitsa pigs are beginning to receive once again the public and media attention. This type of breed is considered a primitive race and in the past the numbers of farms that produced Mangalitsa decreased. Since 2011, this breed has began to grow in numbers, due to the special qualities of the products obtained and the particular traditional processing (Incze et al., 1998).

The particularities of Mangalitsa meat are known but the effect of traditional feeding regime are still not very discussed in the field literature. There is not much information on the effects of grass intake and the meat characteristics, some even suggest that there isn't any (Danielsen et al., 2000). The effects of traditional breeding, which imply outdoor rearing, has also been studied in other breeds but no major differences in the quality of meat were observed (Gentry et al., 2002; Bee Guex and Herzog, 2004). For this matter our study aimed at assessing the biochemical composition 
of meat obtained from Mangalitsa pigs in order to see possible particularities.

\section{MATERIALS AND METHODS}

The material used for this study was represented by 10 Mangalitsa pigs, Blond variety, bought from Hungary at the age of $3-3.5$ months and a live weight of $30-40 \mathrm{~kg}$. The animals were bred in a traditional farm, from Sălaj County, fed with cereals, grass and no concentrates.

The slaughtering was made at 1 year, and the compositional aspects of the meat from various carcass regions were assessed. For the fatty acids and cholesterol determination, sampling was made only from the chop area.

The determination of the compositional parameters

The biochemical parameters were determined with the help of the FoodScan Lab (Foss, Denmark) apparatus according to the standard protocol. This is an automatic system which allows the quantification of the protein, water, fat and collagen in less than 1 minute.

The determination of the energetical value

In the field literature, the nutritive value is often represented under the aspect of chemical composition in percentage, with a particular highlight on the presence of a particular nutrient, or sometimes accompanied by the energetic potential expressed in $\mathrm{kcal} / 100 \mathrm{~g}$ product.

The valuable substances from a nutritive aspect are not assimilated completly in the organism. The assimilation degree depends on a variety of factors, among which: feed regime, processing technology, some physical-chemical properties etc., and it is available for different groups of food products. In the case of meat the degree of assimilation of nutritive substances is: protein - 95\%, lipids - 90\%.

The determination of the energetic values requires the following data in order to be able to calculate: the chemical composition, the average coefficient of assimilation of the various components and the calories. The energetic value was calculated with the following formula:

$$
Q=P \cdot 4,1 \cdot K_{P}+L \cdot 9,3 \cdot K_{L}
$$

Where

$\mathrm{Q}=$ energetic value;

$\mathrm{K}_{\mathrm{p}}, \mathrm{K}_{\mathrm{L}}=$ assimilation coefficient for proteins, respectively lipids;
$4,1 \mathrm{kcal} / \mathrm{g}=$ the caloric coefficient of proteins;

$9,3 \mathrm{kcal} / \mathrm{g}=$ the caloric coefficient of lipids;

\section{The determination of fatty acids and cholesterol level:}

The fatty acids and cholesterol determinations were performed using a protocol previously described by Mihaiu et al., 2011. Briefly, $1 \mu \mathrm{L}$ of the prepared sample was injected into the Shimadzu GC-17A series gas-chromatograph, equipped with a $30 \mathrm{~m}$ polyethylene glycol coated column (Alltech AT-WAX, $0.25 \mathrm{~mm}$ I.D., $0.25 \mu \mathrm{m}$ film thickness). Helium was used as the carrier gas at a pressure of $147 \mathrm{kPa}$. The injector and detector temperatures were set at $260^{\circ} \mathrm{C}$. For the oven temperature the temperature used were: $70^{\circ} \mathrm{C}$ for $2 \mathrm{~min}$. then raised to $150^{\circ} \mathrm{C}$ at $10^{\circ} \mathrm{C} / \mathrm{min}$. rate and held at $150^{\circ} \mathrm{C}$ for $3 \mathrm{~min}$., then further raised up to $235^{\circ} \mathrm{C}$ at a $4^{\circ} \mathrm{C} / \mathrm{min}$.

\section{The statistical evaluation:}

The statistical evaluation was performed in order to evaluate the possible differences in meat composition among the individuals studied. This evaluation was done by performing the ANOVA test (Origin 8.5 software, USA).

\section{RESULTS AND DISCUSSION}

The study showed was able to establish the main biochemical parameters of Mangalitsa meat in the following anatomical region: neck, chop, gammon and shoulders. The averages in of the parameters studied in these particular regions are shown in Tab.1.

As shown in table 1 , the quality of pork meat in these anatomical regions show statistically different values $(p<0.05)$. The gammon revealed a fat percent of minimum $3.89 \%$, followed by shoulder (12.04\%) and chop (12.21), and the neck the highest percent (31.97).

The quantity of water and protein vary in an opposite way compared to the fat percentage. It was found that in the gammon, there is a higher percentage of water $(72,09 \%)$ and protein $(22,51 \%)$, compared to other anatomical regions where the water and protein lowers until it reaches values of 52,93, respectively 15,81 in the case of the neck area.

The content of intra-muscular fat and its equal distribution, is favorable from the aspect of its functionality (flavor, tenderness, juiciness), being 
ideal for steak. The lower content in saturated fatty acids and high in unsaturated fatty acids is very good for human diet. Due to the report between the linoleic and linolenic acid, the oxidation capacity of the fat provided by this breed is low, which implies lower chances for the met to become rancid.

Comparing the composition of fatty acids determined from the back lard and the one revealed from the belly, it was concluded that the back lard contains more saturated fatty acids and less monounsaturated fatty acids (Hollo et al., 2003).

We have found that Mangalitsa fat content is $12 \%$ less saturated fatty acids and $8 \%$ more unsaturated fatty acids than the values reported by other studies on modern pig breeds. For example, Seenger (2007) found a level of saturated fatty acids of $42.95 \%$, compared to our results which show an average of only $35.2 \%$. Also, in Large White the percent of unsaturated fatty acids was reported to be $36.87 \%$.

In a comprehensive study Szabó (2006) analyzed the fatty acid composition of back fat samples from 7 purebred (including Blonde and Red Mangalitsa) and 3 crossbred genotype. They found the lowest ratio of saturated fatty acid in
Red Mangalitsa (36.99\%) and the highest ratio in Duroc x Cornwall hybrid (44.65\%). Among the pure breed Szabó and Farkas found the highest ratio for saturated fatty acids of 43.175 in Duroc breed (Nistor et al., 2012). The results concerning the fatty acid percentages are shown in Tab. 2 .

Following a study made by the Hungarian Research Institute, it was revealed that there no significant differences in the total protein content found in Mangalitsa breed compared to the Large White breed. The mean cholesterol level obtained in our study was $53 \mathrm{mg} / 100 \mathrm{~g}$. Compared to other breeds there are no differences in the cholesterol levels due to the extended growth and fattening period, the vitamins and minerals having much more time to accumulate in the meat tissues. These have a crucial importance for the human health and represent a surplus in value for the Mangalitsa pigs and meat products, creating an advantage in the competition with other types of meat products.

The Mangalitsa meat and fat does not contain less cholesterol levels than other breeds of pigs. The cholesterol is the natural component of each cell, being the base for vitamin D syntesis and steroid hormones. The meat cholesterol content

Tab. 1. The chemical compositions of the pork meat from Mangalitsa breed according to the anatomical parts

\begin{tabular}{cccccc}
\hline & Water (\%) & Fat (\%) & Protein (\%) & Collagen (\%) & $\begin{array}{c}\text { Collagen/ } \\
\text { Protein (\%) }\end{array}$ \\
\hline Chop & 66,04 & 12,21 & 21,58 & 1,90 & 8,8 \\
\hline Gammon & 72,09 & 3,89 & 22,51 & 1,67 & 7,42 \\
\hline Shoulder & 67,25 & 12,04 & 20,03 & 2,27 & 11,33 \\
\hline Neck & 52,93 & 31,97 & 15,81 & 2,48 & 15,69 \\
\hline
\end{tabular}

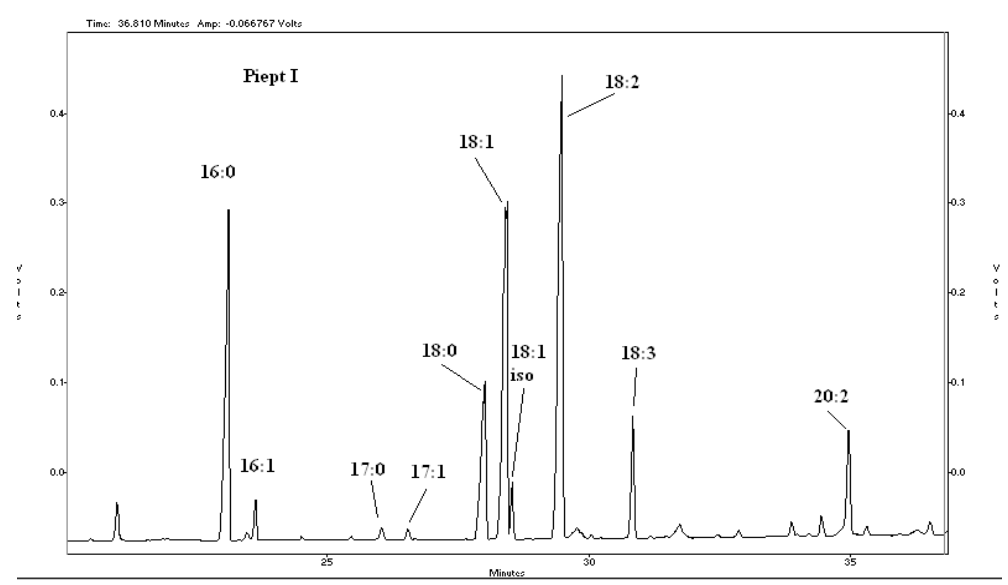

Fig. 1. Fatty acids chromatogram from a representative sample 
is relatively low (50-90 mg/100 g) compared to other types of products such as: liver 200-900 $\mathrm{mg} / 100 \mathrm{~g}$, egg yolk $1190 \mathrm{mg} / 100 \mathrm{~g}$, or brain 3000 mg/100 g. (Kovács and Zsarnóczay, 2003).

Following the calculations made, in what concerns the energetic value of Mangalitsa pigs, the minimum number of calories / $100 \mathrm{~g}$ product is given by the meat from gammon area, 120,24kcal, and the maximum level of calories is given by the meat provided from the neck ( $307 \mathrm{kcal})$. The value found in this anatomical area is almost triple than the one revealed at the gammon.

\section{CONCLUSION}

Mangalitsa meat, due to its particular nutritive features may be considered a functional food for human diet. Based on the protein and cholesterol levels, the healthiest meat can be considered the one provided by the gammon and shoulder areas. Even though the fat layer is more developed than in other breeds, the cholesterol levels are the same as in the other selected breeds. We strongly recommend the reinvestments in this breed, given the particular health benefits that it might bring compared to other sources of meat.

Tab. 2.The mean values of the fatty acids in comparison to other study made on the same breed

\begin{tabular}{|c|c|c|c|c|}
\hline \multirow[b]{2}{*}{ Trait } & \multirow[b]{2}{*}{ Symbol } & \multicolumn{2}{|c|}{$X \pm S_{x}$} & \multirow[b]{2}{*}{$\begin{array}{c}\text { Valoarea } p \\
p \text { - value }\end{array}$} \\
\hline & & $\begin{array}{l}\text { Mangalitsa } \\
\text { (our study) }\end{array}$ & $\begin{array}{c}\text { Mangalitsa } \\
\text { (Parunovic et } \\
\text { al. 2012) }\end{array}$ & \\
\hline Miristic & $\mathrm{C} 14: 0$ & $1.36 \pm 0.12$ & $1.24 \pm 0.019$ & NS \\
\hline Palmitic & C16:0 & $23.96 \pm 0.61$ & $24.6 \pm 0.215$ & NS \\
\hline Stearic & C18:0 & $9.63 \pm 0.28$ & $9.24 \pm 0.248$ & NS \\
\hline Palmitoleic & C16:1 & $3.57 \pm 0.80$ & $4.86 \pm 0.182$ & $*$ \\
\hline Oleic & C18:1 & $40.69 \pm 7.31$ & $44.3 \pm 0.472$ & $* *$ \\
\hline Miristoleic & C14:1 & $0.55 \pm 0.11$ & - & ND \\
\hline Linoleic & C18:2 & $4.16 \pm 0.37$ & $4.90 \pm 0.437$ & NS \\
\hline Linolenic & C18:3n3 & $0.44 \pm 0.21$ & $0.536 \pm 0.039$ & NS \\
\hline \multicolumn{2}{|c|}{ SFA } & $35.15 \pm 0.23$ & $35.5 \pm 0.375$ & NS \\
\hline \multicolumn{2}{|c|}{ MUFA } & $46.18 \pm 2.98$ & $55.5 \pm 0.681$ & $* *$ \\
\hline \multicolumn{2}{|c|}{ PUFA } & $6.71 \pm 1.18$ & $6.45 \pm 0.502$ & NS \\
\hline
\end{tabular}

NS - not significant $\mathrm{P}>0,5$; Significant:* $\mathrm{P}<0,5$; ${ }^{*} \mathrm{P}<0,01$; ${ }^{* *} \mathrm{P}<0,001$

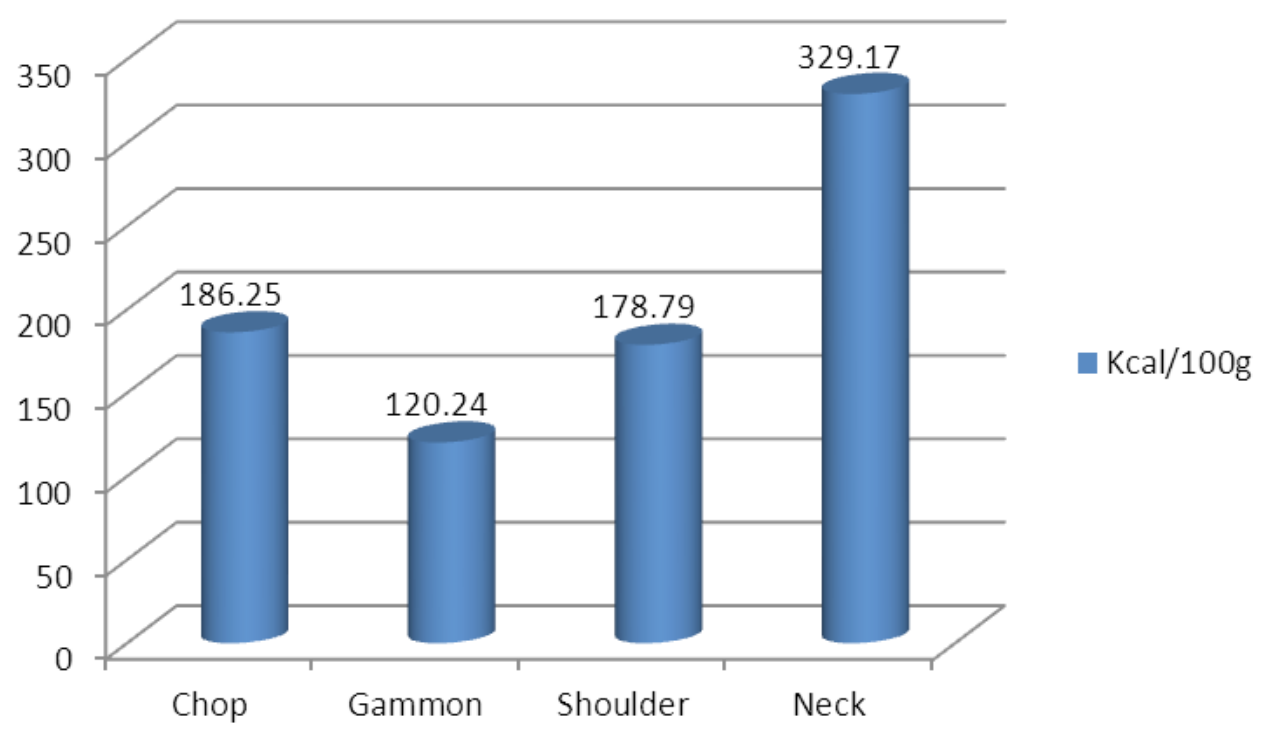

Fig. 2. The energetic value of Mangalitsa meat according to the anatomical regions 
Acknowledgments. This paper was published under the frame of European Social Fund, Human Resources Development Operational Programme 2007-2013, project no.POSDRU/159/1.5/ S/136893.

\section{REFERENCES}

1. Alonso V, Campo Maria del Mar, Provincial L, Roncalés P, Beltrán JA (2010). Effect of protein level in commercial diets on pork meat quality. Meat Science 85:7-14.

2. Bee G, Guex G, Herzog W (2004). Free-range rearing of pigs during the winter: adaptations in muscle fiber characteristics and effects on adipose tissue composition and meat quality traits. J Anim Sci 82:1206-1218.

3. Danielsen V, Hansen LL, Moller F, Bejerholm C, Nielsen S, Hermansen JE (2000) Ecological animal husbandry in the Nordic countries. In: Proc NJF-seminar 303, Horsens, Denmark, 16-17 September 1999, 79-86.

4. Gentry JG, McGlone JJ, Blanton JR, Miller MF (2002). Impact of spontaneous exercise on performance, meat quality, and muscle fiber characteristics of growing/ finishing pigs. J Anim Sci 80:2833-2839.

5. Holló GJ, Seregi K, Ender K, Nürnberg J, Wegner J, Seeger I, Holló I, Repa (2003). Examination of meat quality and fatty acid composition of Mangalitsa. Acta Agraria Kaposvariensis 7(2):19- 32.

6. Incze K, Zukál E, Szerdahelyi K, Erdős Z (1998). Az alapanyag-feldolgozás és a piacra jutás folyamatainak minıségi ugrópontjai a húsipari termékeknél" Agro-21 Füzetek 5-31.

7. Kovács Á, Zsarnóczay G (2003). Development of traditional pork (Mangalitza) production value chain, Hungarian Meat Research Institute, Budapest.

8. Mihaiu M, Alexandra L?puşan, Bele C, Mihaiu R, Dan SD, Taulescu C, Matea C (2011). The assessment of the quality and traceability biomarkers in the buffalo milk primary production, Roumanian Biotechnological Letters 16:123.

9. Nistor E, Bampidis V, Pentea M, Prundeanu H, Ciolac V (2012). Nutritional Quality of Pork Produced by Mangalitsa Breed. Animal Science and Biotechnologies $45(2)$.

10. Seenger JK (2007). The effect of slaughter weigth and genotype on the fatty acid composition of intramuscular and subcutaneous fat in pigs. Theses of Ph.D. Dissertation, Szent István University, Gödöllő, Faculty of Agicultural and Environmental Sciences, 1-22.

11. Szabo P (2006). Fatty acid composition of the tissues of Mangalica and other pig genotypes. Hungarian J Anim Prod 55:293-311. 